\title{
格子型砂防ダムの閉塞モデル STOCHASTIC MODEL OF BLOCKING FOR A GRID-TYPE DAM BY LARGE BOULDERS IN A DEBRIS FLOW
}

\author{
高橋 保 1 -中川 - 2 - 里深好文 $3 \cdot$ 王浩民 4 \\ Tamotsu TAKAHASH,Hajime NAKAGAWA, Yoshifumi SATOFUKA and Haomin WANG \\ 1 フェロー 工博 京都大学教授 京都大学防災研究所（†611 宇治市五ヶ庄） \\ 2 正会員 工博 京都大学助教授 京都大学防災研究所 (T611 宇治市五ヶ生) \\ 3 正会員 工修 京都大学教授助手 京都大学防災研究所（广611 宇治市五ヶ生） \\ 4 学生会員 京都大学大学院工学研究科 土木工学専攻（T606 京都市吉田本町）
}

\begin{abstract}
Debris flow disaster can be reduced by a grid-type dam, which traps large boulders but passes small size sediments in a debris flow through it. Various models have been developed to predict the trap rate of sediments by a grid-type dam using the characteristics of a debris flow and a grid-type dam. Experimental results show that a little difference of arrival time of a large boulder at a grid-type dam markedly affects the blocking mechanism even though the other conditions are the same. In this research, the blocking phenomenon is regarded as a stochastic process and a new stochastic model of blocking for a grid-type dam by large boulders in a debris flow is proposed. The experimental results of the blockage process of a grid-type dam were fairly well explained by this model.
\end{abstract}

Key Words : debris flow; grid-type dam; stochastic process; blocking

\section{1.はじめに}

近年, 人間の生活空間は山地流域や河川周辺に広がっ ており，土砂の生産・流送などの土砂移動現象が，人々 の生活に直接的な影響を与えている。特に，土石流災害 は死者を伴う自然災害の中て大きな比重を占めており， その防止・軽娍刘策は，社会的に極更重要な課題とな っている。そのため, 従来から異常豪雨時の土石流ある いは土砂流の調節制御をはじめ各種の目的を持って, 数 多くのコンクリート製不透過型砂防ダムが設置されてき ている。しかし，この種の砂防ダムでは土石流や多量の 土砂流出を伴うような大洪水が発生する前の小規模の出 水で満砂し, 肝心の大洪水時に, 十分な土砂調節の機能 を果たさない場合も少なくない。その上これらのダム は土石流を一旦経験すると, 殆どの場合満砂に近い状態 になるため, 目的とする土石流調節機能も失われること が多い。且つ, 中小洪水時の流仯を遮断するため, 下流 河川の水みちが固定化され，河川内の砂州の樹林化をう ながすとともに，魚などの生活にも悪影響を及ぼすなど の原因ともなっている。上記のような欠点への反省から， 最近になって，土砂を止めることを目標にする砂防から， 危険な土砂流出は確実に抑止し，その上で，下流の生態 環境等を保全するために，安全無害な土砂は継続的に流
下させる砂防への考え方の転換がなされている。無害な 土砂は下流へ流すという思想は古くからあり，一部で大 暗渠ダムが建設されていたが，暗渠部分が壊れやすく， 維持が困難であることから次第に顧みられなくなってい た。しかしながら，満砂ダムが十分に土石流調節機能を 発揮しないという久点を払拭するために，約 20 年前に透 過型砂防ダムが注目されることになった。これは通常の 出水で移動するような小さな砂碩は暒堤に設けられた隙 間から流出させることにより，砂防ダムが満砂して空容 量を失うことを防ぎ，土石流の発生時には，その先端部 に集中する巨石により隙閒が閉塞されることを利用し， ダム上流域に土石流を堆積させようとするものである。 透過型砂防ダムが土石流を確実に捕捉するためには, その透過部分が確実に閉塞しなければならない。従来の 研究によると, 透過部分の空間幅 $L$ と砂砶の最大粒径 $d_{\max }$ との比や土砂濃度などのパラメータがこの透過部 分の閉塞に大きく影響を及ぼすことがわかっている。 1)2313透過性砂防ダムの一種類である格子型砂防ダムの土 石流捕捉モデルに関しては，土砂通過量を確率的に決め

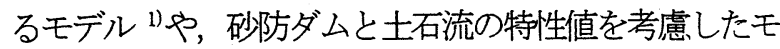
デル2) などの提案がなされているが, いずれのモデルに おいても土石流の流入条件及びダムの特性值が与えられ ると，「確定的」に土石流の捕捉率などが決定される。と ころが，実際には，同じ条件であっても，大きな粒子の 
到着タイミングのわずかのずれなどの影響でダムが閉塞 したりしなかったりすることが知られている。そこで, 本研究では, 透過部の閉塞現象は一つの「確率過程」で あり, 瞬間閉塞確率は石䂺濃度, 最大粓径, 移動速度等 の土石流特性值と関係づけられるものと考え, 時間の経 過に伴うダムの閉塞過程を再現できるモデルを開発する。

\section{2. 実験概要}

\section{(1) 実験装置，方法}

奏験装置を図一 1 に示している。幅 $10 \mathrm{~cm}$, 勾配 18 度 の水路の上に取り付けている 30 度の滑り台から, 粒径 1 $\mathrm{cm}$ の一様砂磁を一定流量の給水条件下て水路に給砂し， 下流端に設置した格子型砂防ダム透過部の閉塞状況と閉 塞パターンを明らかにする。さらに，砂礫の数や給水量 を種々変化させることによって，格子ダム透過部にやっ てくる砂砶材料の濃度と速度を変え, 格子の閉塞状況の 違いを明らかにする。

実験条件を表-1に示す。ここに，vは砂礫の速度，c は濃度, $t_{m}$ は砂碩の平均到着時間間隔, $t_{0.2 \sim 0.4}$ は閉塞確 率 0.2 - 0.4 に達するまで所要時間である。なお, 閉塞確 率について次節で述べる。

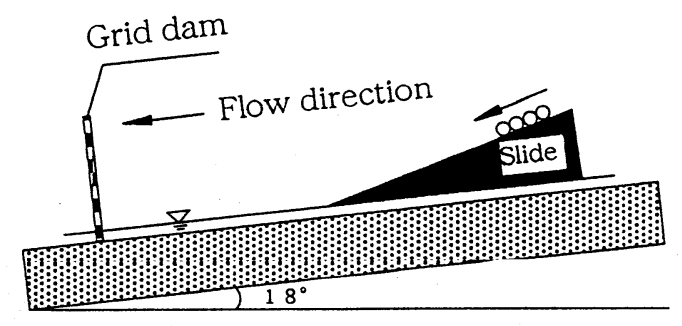

図-1 実験水路

実験に使用した格子型砂防ダムを図-2に示す。ダム部 材には直径 $3 \mathrm{~mm}$ の銅製捧を用いている。格子間隔 $L$ と粒 径 $d$ の比は 1.7 である。

\section{(2) データ処理方法}

実験中，格子型砂防ダムの下流側と側面より，デジタ ルビデオカメラで，上方より高速ビデオカメラで砂礫の 動きを追跡し，ダム透過部の閉塞過程を撮影した。映像 記録は動体解析ソフトMove-tr32/3D を使って，0.01 秒ご とにダムの透過部に到達した粒子の数と各々の速度を解 析し，ダムの格子が閉塞した時刻を計測した。これによ って, 砂磪材料の平均濃度と平均速度を算出した。

また，実験に使用した格子型砂防ダムには横断面内に 一列で五つの格子があるが，格子の間の相互的な影響を 無視し，五つの格子に対する一回の試行が一つの格子に 対する五回の試行と同じであると見なして,一つの格子 が閉塞した時，格子の閉塞確率が $20 \%$ 増え，全部の格子
が閉塞した時，閉塞確率が 100\%に達したと考える。

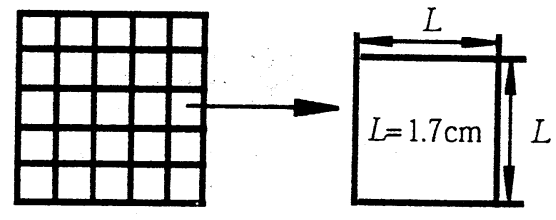

図-2 実験用模型ダム

表-1 実験条件

\begin{tabular}{|c|c|c|c|c|}
\hline CASE & $v(\mathrm{~cm} / \mathrm{sec})$ & $c$ & $t_{m}(\mathrm{sec})$ & $t_{0.2-0.7}(\mathrm{sec})$ \\
\hline \hline 1 & 14.3 & 0.039 & 0.469 & 0.6 \\
\hline 2 & 15.7 & 0.031 & 0.538 & 0.71 \\
\hline 3 & 15.9 & 0.047 & 0.350 & 0.35 \\
\hline 4 & 15.9 & 0.03 & 0.549 & 0.76 \\
\hline 5 & 16.5 & 0.031 & 0.512 & 0.54 \\
\hline 6 & 13.7 & 0.07 & 0.273 & 0.27 \\
\hline 7 & 13.8 & 0.051 & 0.372 & 0.72 \\
\hline 8 & 13.3 & 0.056 & 0.352 & 0.57 \\
\hline 9 & 13.6 & 0.069 & 0.279 & 0.25 \\
\hline 11 & 14 & 0.07 & 0.267 & 0.23 \\
\hline 12 & 14.2 & 0.066 & 0.279 & 0.31 \\
\hline 13 & 13.9 & 0.124 & 0.152 & 0.06 \\
\hline 14 & 13.9 & 0.096 & 0.196 & 0.18 \\
\hline 15 & 14.3 & 0.08 & 0.229 & 0.37 \\
\hline 18 & 16.5 & 0.077 & 0.206 & 0.2 \\
\hline 19 & 17.6 & 0.084 & 0.177 & 0.14 \\
\hline 20 & 15.9 & 0.103 & 0.160 & 0.07 \\
\hline 21 & 17 & 0.106 & 0.145 & 0.04 \\
\hline 22 & 17.3 & 0.112 & 0.135 & 0.04 \\
\hline
\end{tabular}

\section{3. 閉塞モデル}

\section{(1) 平均到着時間間隔 $t_{m}$}

急勾配の渓床堆積物が表面流によって侵食され，その 水と侵食土砂が混合して流下するというプロセスで形成 される土石流は, 通常粘土粒子から直径数メートルの巨 礫まで広い粒度分布を持っている。土石流先端部付近に は最大径クラスの粒子が集まっているので，この部分で は, 最大径 $d_{\max }$ を持つ粒子がランダムな時間間隔で格子 ダム透過部に到達すると考える。従来の研究引により，格 子ダム透過部の閉塞には， $L / d_{\max }$ が大きく影響してい ることがわかっているが， $d_{\max }$ の粒径粒子が透過部に到 達する頻度も関係すると考えられる。今, 格子の両柱の 中心間距離を $\ell$ とすると，この区間に粒子が到達する平 均の時間間隔 $t_{m}$ は, 粒子の平均濃度 $c$, 粒子の平均移動 速度 $v$ ，粒径 $d$ を用いると，次式で表される

$$
t_{m}=\frac{\pi d^{2}}{6 \ell c v}
$$

$t_{m}$ がしに依存する理由は以下のようである。即ち, 図-3

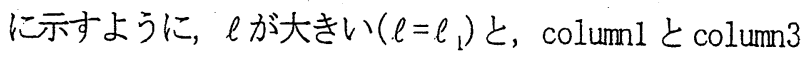


の間に粒子1から粒子9までが次々と到着して， $t_{m}$ が小さ くなるが $\left(t_{m}=t_{m 1}\right), \ell$ が小さくなると $\left(\ell=\ell_{2}\right)$, 粒子 1 、 $4 、 7$ が column1 と column2 の間に到着することになり，濃 度が一定でも $t_{m}$ は大きくなることがわかる $\left(t_{m}=t_{m 2}\right)$ 。

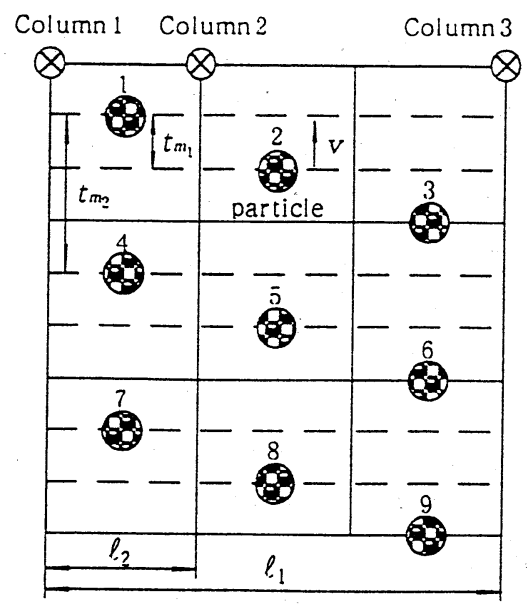

図-3 平均到着時間間隔 $t_{m}$ と $\ell$ との関係

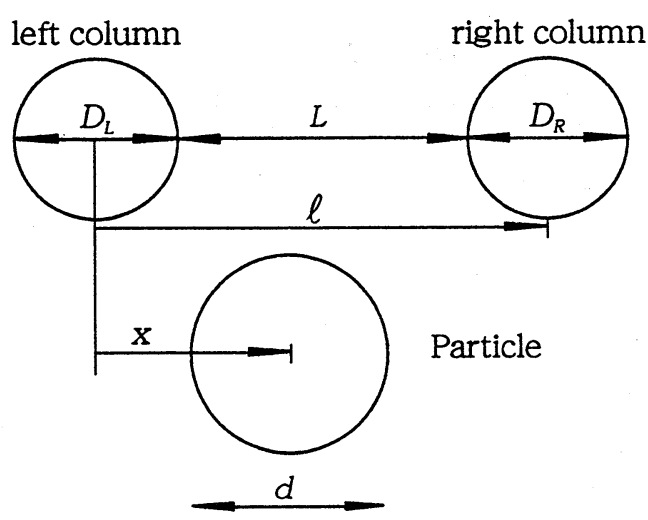

図-4＼cjkstart粒子とダムの柱との位置関係

また， cとvが大きいほど，閉塞確率は大きくなると予 想される。表-1において, case2 と case5 を比較すると, 同一粒子濃度では流速が大きい case 5 の方が $t_{m}$ は小さく， また, case3 と case4 を比較すると，同一流速では粒子濃 度が高い case3 の方が $t_{m}$ は小さくなっており，式(1)の傾 向を示している。 $t_{m}$ が小さい場合閉塞しやすくなると考 えられるが， $t_{0.22-0.4}$ も小さくなり，このことを裏付ける結 果となっている。

\section{(2) 閉塞パターン}

実験中の観察によると，粒子の到達位置によって，粒 子がダムの柱に衝突する場合と衝突しない場合の二通り があった。図-4に粒子と柱の位置関係を示す。

同図より，粒子が柱に衝突する条件は次で表される。 左側の柱に衝突

$$
x<\frac{D_{L}+d}{2}
$$

$$
\text { 右側の柱に衝突 } \quad x>\ell-\frac{D_{R}+d}{2}
$$

ここに， $x$ は左側の柱の中心と粒子の中心との間の距離, $D_{L}$ は左側の柱の直径， $D_{R}$ は右側の柱の直径である。

粒子がある角度でダムの柱に当たった後，柱を中心と してある角速度 $\omega$ で接点で髇ずに回転しながら移動す ると考える。実験によって，図-5 のような回転中の粒子 とその後到着する粒子との間でアーチアクションを作る ことにより，透過部が閉塞することが判明した。

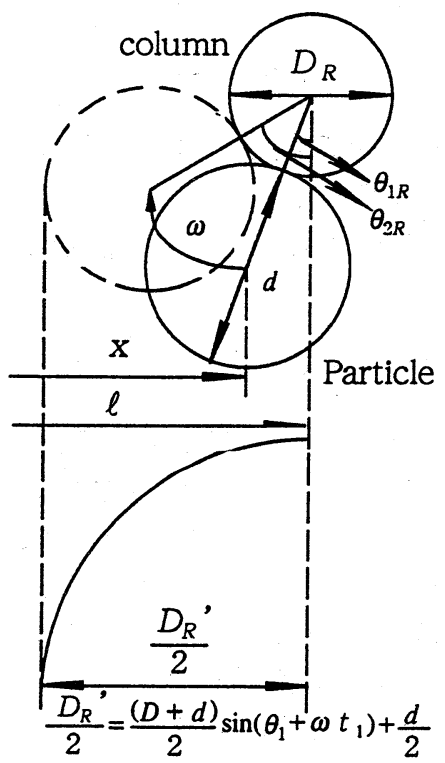

図-5ダムの柱を中心とする衝突粒子の回転過程

これらの実験結果をもとに，次のような閉塞モデルを 考えた。粒子が柱を軸に回転している間は，後続粒子の 通過可能間隔Lが小さくなる。すなわち, 粒子が接してい る柱の直径が大きくなったのと等価であると考える。そ のパターンは以下の 3 つに大別できる。

パターン $1: i$ 番目にやってきた粒子がどちらの柱にも当 たらないで通過する。この場合, 後出の図-8に示すフロ 一チャートにおい、て， $i+1$ 番目の粒子の衝突判定に進み， $T_{L}$ 時間内にやってくる粒子が全て通過する場合には, $T_{L}$ 時間内では閉塞しなかったと考える。 パターン $2: 2$ 個の粒子が同時に到達して閉塞する。 パターン $3:$ 片方の柱に粒子が衝突して回転中に, 後続 の粒子が回転中の粒子に衝突し, 徐々に閉塞する。この 場合は, 柱の直径が大きくなると考え，新しい $D_{L}, D_{R}$ を計算し， $D_{L}+D_{R}>L$ となれば，たとえ一時的にでも， 透過部が閉塞したと考える。

だたし，複数の粒子が連続して流下してくる場合，次 の粒子が流下してくる位置によっては，見掛け上太くな った柱に接触しても，直径を増加させる方向に回転しな い場合も生じるので，粒子が見掛け上の柱を太くする条 件は次式のようになる。 
左の柱に衝突 $\quad \frac{D_{L}-d}{2}<x<\frac{D_{L}+d}{2}$

右の柱に衝突

$$
\ell-\frac{D_{R}+d}{2}<x<\ell-\frac{D_{R}-d}{2}
$$

\section{(3) 柱の直径の計算}

上式によって，位置 $x$ を流下してきた粒子が粒子の中 心と柱の中心を結ぶ角度が $\theta_{1}$ の位置で柱に衝突して，柱 を中心に一定の角速度 $\omega$ で回転し，限界角度 $\theta_{2}$ で離脱す ると考えると，離脱に要する時間 $t_{w}$ は下式で表される。

$$
t_{w}=\frac{\theta_{2}-\theta_{1}}{\omega}
$$

実験によれば，限界角度 $\theta_{2}$ は60～65 度である。

今, 衝突 $t_{1}$ 秒後の角度を $\theta\left(\theta_{1}<\theta<\theta_{2}\right)$ とすると, 図 -5 に示すように増大したとみなされる柱の直径 $D^{\prime}$ は次式 で表される。

$$
D^{\prime}=(D+d) \sin \left(\theta_{1}+\omega t_{1}\right)+d
$$

ただし， $D^{\prime}>d$ の時， $D^{\prime}$ の最小值は $D$ とする。

また， $M$ 個の粒子が引き続いて接触する場合は，図一 に示すように時刻 $t$ において，太くなった柱に対して次の 粒子がやってくるとすると，柱の元の直径 $D_{0}$ から一段目 の新しい直径 $D_{1}$ を計算し, $M-1$ 段目の直径 $D_{M-1}$ から $M$ 段目の直径 $D_{M}$ を計算するというようにして, 時刻 $t$ での見掛け上の直径を計算する。ここに，時刻 $t_{s 1}$ に最初 の粒子が柱に衝突し， $t_{s 2}$ に回転中の最初の粒子に 2 番目 の粒子が衝突するというように記している。但し，ある下 層の粒子が限界角度を過ぎる場合は，その粒子自身とそれ より上層の粒子が全部崩れて，見掛け上の直径が瞬間的に その粒子の直下層粒子の見掛け上の直径まで戻ると考え る。最下層の粒子が崩れた場合は元の柱の直径に戻ると考 える。図中の $t_{e 1} 、 t_{e 2} 、 t_{e 3}$ は柱加ら粒子或いは粒子同士の 接触力離九る時刻を示している。勿論時刻 $t$ における見か け上の直径 $D_{3}$ が $L$ より大きい場合は，その格子は閉塞す ると考える。

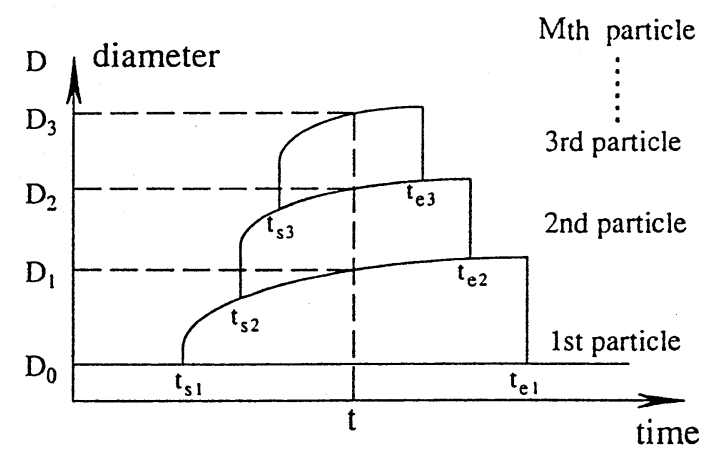

図-6＼cjkstart見掛け上の柱の直径の計算

\section{(4) 回転角速度 $\omega$ の計算}

粒子が速度 $v$ で跳ね返りなく柱に衝突して，摩擦力等 を無視するとすると, 粒子と柱の接触点に関して, 粒子
に作用するカのモーメントがゼロであるので，角運動量 保存則を適用することができる。そこで，図-5 を参照して， 接点回りの角運動量の保存を考えると, 次式が成立する。

$$
\frac{1}{2} m v d \sin \theta=\left\{I_{o}+m(d / 2)^{2}\right\} \omega
$$

ここに， $m$ は粒子の質量， $I_{0}$ は粒子を球状と仮定した場 合の重心回りの慣性モーメントである。また，衝突後，粒 子は接触点に対する回転運動だけをして，衝突によるエ ネルギー損失が無視できると仮定すると，回転角速度 $\omega$ は 式(8)より次式のように求められる。

$$
\omega=\frac{10}{7 .} \frac{v}{d} \sin \theta
$$

ところが，このように求めた回転角速度 $\omega$ はエネルギ 一損失を考慮していないため, 角速度の修正が必要であ る。各ケースで任意に 50 個の粒子をサンプリングし，各 粒子の角速度の実験值と計算値の比較を図-7 に示してい る。回帰分析により，角速度を次式のように修正する。

$$
\omega=1.278 \frac{v}{d} \sin \theta+0.094
$$

式（9）を用いた場合の適合度は $R^{2}=0.8852$ である。

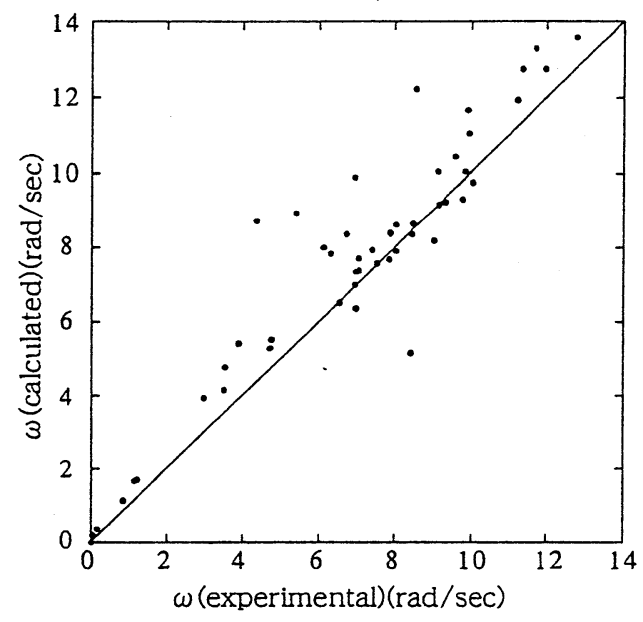

図-7 回転速度の計算値と実験值との比較

\section{(5) 閉塞モデル}

閉塞モデルのフローチャートを図-8に示す。今, 土砂 濃度 $c$ ，速度 $v$ が一定であるとして，ある時間間隔 $T_{L}$ の 間に, $i$ 個の粒子がランダムな時間 $t_{i}\left(0<t_{i}<T_{L}\right)$ に, ランダムな位置 $x_{i}$ 上を流下してきて, ダム透過部一到達 すると考えると, 粒子と柱との衝突の有無によって, 新 しい柱の直径を計算し，ダムが閉塞するかどうかを判断 する。すなわち， $T_{L}$ の間に $i$ 回の試行をし，そのつどダ ムが閉塞するかどうかを判定する。最終的 $\left(t=T_{L}\right)$ に閉 塞したかどうかを判定し, 同じ条件下で $N$ 回繰り返すと， $T_{L}$ 時間内での閉塞確率 $F$ は以下のように求められる。

$$
F=\text { 閉塞した回数 } / N
$$

さらに, $T_{L}$ を変えて計算すれば, $T_{L}$ と $F$ との関係が 離散的に求められる。しかし，実際の数值解析に用いる 
閉塞確率は $T_{L}$ より遙かに小さい時間間隔 $\Delta t$ に対する瞬 間閉塞確率 $P$ でなければならないので, 図-9 のように $P$ を $F$ を用いて表しておくことが必要である。そこで， 今， $、 v v$ が一定であるならば， $P$ が一定であると考え ると, $T_{L}=n \Delta t$ 秒後の閉塞確率は $F=1-(1-P)^{n}$ となる ので， $P$ を求めることができる。

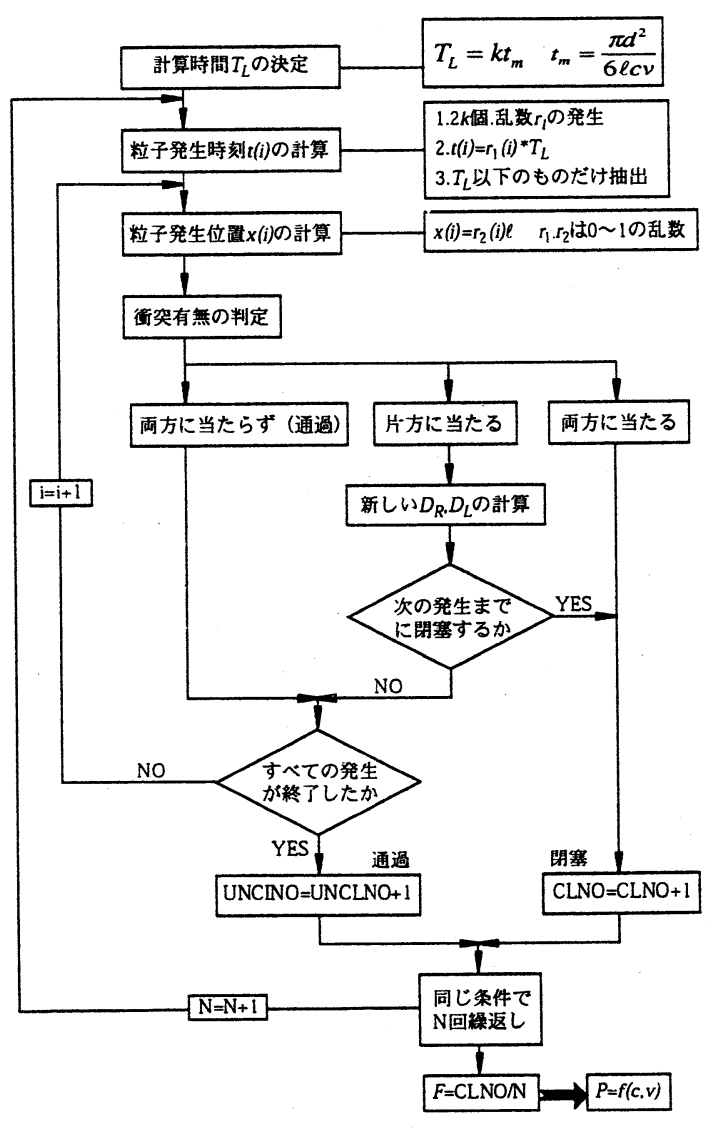

図-8＼cjkstart閉塞モデルのフローチャート

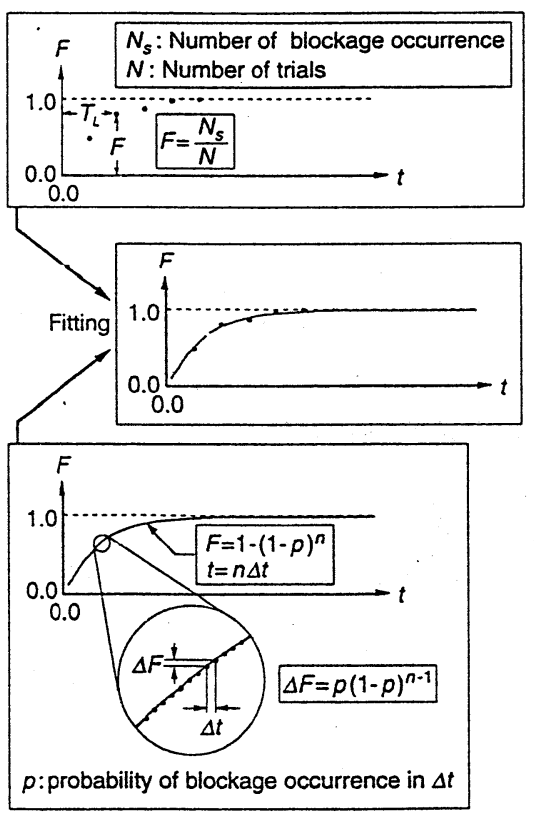

図-9 瞬間閉塞確率の計算
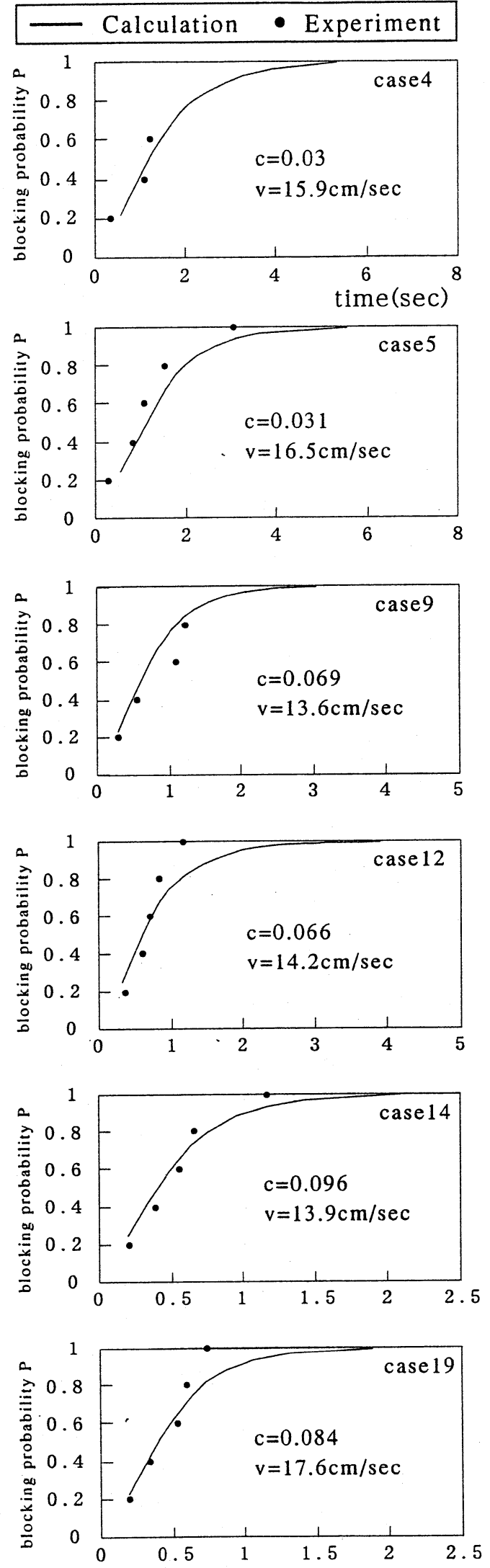

図-10 閉塞確率の実験值と計算値との比較

\section{4. 数值解析及び結果}

前述した格子型ダムの閉塞に関する実験と同様の 
条件のもとでこのモデルを用いて, 瞬間閉塞確率 $P$ に関 する数值解析を行った。図-10は閉塞確率 $F$ の計算值と 実験值を比較した例である。この図によれば，閉塞確率 が大きくなるにつれて，閉塞確率の実験值と計算值との 差が大きくなっているが，計算值は実験值の傾向を比較 的よく再現している。

図-11は閉塞確率0.4ー0.6に達するまでの所要時間の 実験値と計算値を比較したものである。平均到達時間 $t_{m}$ が小さい場合に両者はよく一致している。これは短時間 により多くの粒子がやってくる時の方が本モデルの考え 方に近い実験条件となるからであろう。

最後に, $N=1000, \Delta t=0.01$ 秒の時の瞬間閉塞確率 の計算結果を図-12 に示している。この図から,一定の $c$, $v$ の条件下における $\Delta t$ に対する瞬間閉塞確率， $P$ が求 められる。

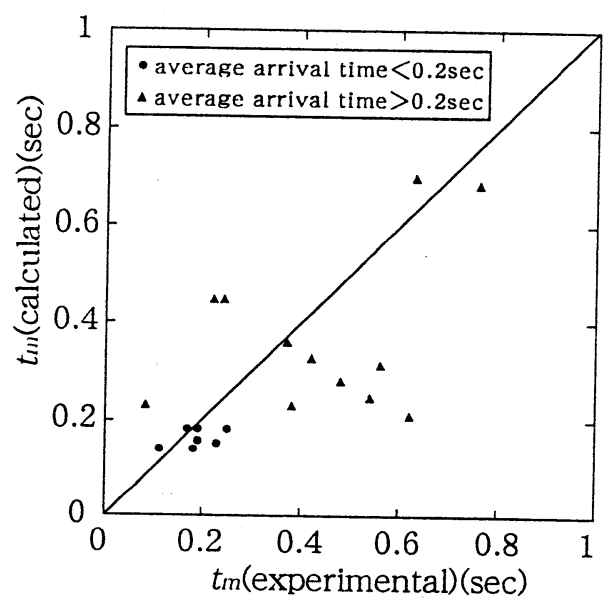

図-11 閉塞確率 0.4から 0.6 に達するまで 所要時間の実験值と計算値との比較

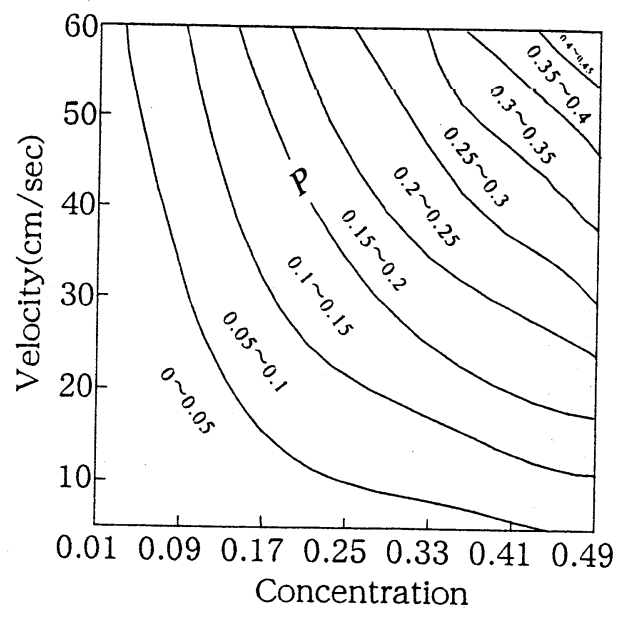

図-12 瞬間閉塞確率の計算結果

5. おわりに
らかにすることを目的として，特に透過型砂方ダムの一 種類である格子型砂防ダムの巨磪の閉塞確率の評価法に ついて検討した。まず，格子型砂防ダム透過部の閉塞過 程に関して実験的な研究を行い，閉塞に影響を及ぼす要 因を明らかにした上で，それらの要因を考慮した巨礫の 捕捉モデルを提案した。また，このモデルを用いて格子 型砂防ダムの閉塞過程に関する再現計算を行った。本研 究で得られた成果と今後の課題は以下のようである。 1. 実験によって, 格子型砂防ダムの閉塞に大きく影響を 及ぼす格子の両柱中心の間の距離 $(\ell)$ と砂礫の最大粒 径 $\left(d_{\max }\right)$ との比や土石流の土砂濃度, 速度などの要因 を確かめた上で，粒子の平均到達時間間隔の概念を提案 した。平均到達時間間隔が小さいほど，格子型砂防ダム の閉塞確率が大きくなることが示された。

2. 格子型砂防ダムの閉塞モデルを提案した。格子型砂防 ダムの閉塞を一つの確率過程として，一定の土石流の条 件下における瞬間閉塞確率 $P$ を求め, これによってダム が閉塞するかどうかを判断するものである。このモデル によって, 格子ダムの閉塞過程をある程度再現できるこ とが判明した。この格子型砂防ダム閉塞モデルと連続体 の原理に基づいた土石流の流動モデルを組み合わせるこ とによって，格子型砂防ダムの土石流調節効果を評価す ることができると考えられるので，今後はその検討を行 う予定である。

謝辞 : 最後に，本研究の一部は文部省科学研究費（基盤 研究 $\mathrm{B}$ (2) 研究代表者 高橋保, 研究課題名 水系一貫 した土砂配分システムの開発，課題番号 11558048 及び 基盤研究C(2) 研究代表者 中川一，研究課題名 透過 型砂防ダムの機能評価と流域土砂管理に関する研究，課 題番号 11650525）の補助を受けて行ったものであり, 関係各位に記して謝意を表する。

\section{参考文献}

1) 芦田和男・江頭進治·栗田三津雄・荒牧浩（1987）：透過性砂 防ダムの土石流調節機構，京都大学防災研究所年報，第 30 号 B-2, pp. 441-456.

2) 水山高久 ・小橋澄治・水野秀明（1995）: 格子型ダムのピーク 流砂量减率に関する研究, 新砂防, Vol. 47 No. 5(196), January, pp. 8-13.

3)芦田和男・高橋保（1980）: 土石流の調節制御に関する研究, 京都大学防災研究所年報, 第 23 号 B-2, pp. 433-441.

（2000. 10. 2受付） 